\title{
EFFECTS OF PRÉCIS-WRITING ON STUDENTS' RECOUNT WRITING AT ENGLISH LABORATORY OF UNIVERSITAS BANDAR LAMPUNG
}

\author{
Miftahul Jannah* \\ miftahuljanah050@gmail.com \\ Universitas Bandar Lampung
}

\author{
Harpain \\ Universitas Bandar \\ Lampung
}

\author{
Yanuar Dwi Prastyo \\ Universitas Bandar \\ Lampung
}

\begin{abstract}
Précis-writing is defined as the technique which engages the process of a précis which is a summary of a written composition (Bromly \& Karen, 1983). Précis-writing technique facilitates the students to summarize reading texts by noting important points from the text and then use them in their writing. This study aims to find out whether précis-writing is more effective in improving students'recount writing than conventional teaching. Thirty of third level English laboratory students participated in this study. They were divided into two classes, the experimental class and the control class of 15 students respectively. They were trained during three meetings to apply précis-writing and conventional teaching for their recount writing. In the experimental class, the students received learning recount writing using précis-writing; while in the control class, the students received training of recount writing using conventional teaching. The data were collected through recount writing tests before and after the treatment. In order to see if précis-writing improved students recount writing, paired-samples t-test was conducted to students' pretest and posttest scores in the experimental class. The result indicated that précis-writing significantly improved students recount writing. Furthermore, independent samples t-test analysis was also conducted to see if précis-writing implemented in the experimental class is more effective than conventional teaching implemented in the control class. The result showed that the significance value was $<.05$ which means that préciswriting is more effective in improving students' recount writing compared to the conventional teaching. Therefore, it can be concluded that précis-writing improved the students' recount writing better than conventional teaching.
\end{abstract}

Key word: Précis-writing, Recount text, English laboratory students.

\section{Abstrak}

Précis-writing adalah teknik yang melibatkan proses précis yang merupakan ringkasan dari komposisi tertulis (Bromly \& Karen, 1983). Teknik Précis-writing memudahkan mahasiswa untuk merangkum teks bacaan dengan mencatat poin-poin penting dari teks tersebut dan kemudian digunakan ke dalam tulisan mereka. Penelitian ini bertujuan untuk mengetahui apakah teknik précis-writing lebih efektif untuk meningkatkan tulisan recount mahasiswa dibandingkan dengan pengajaran konvensional. Tiga puluh mahasiswa dari Laboratorium Bahasa Inggris tingkat tiga berpartisipasi dalam penelitian ini. Mereka dibagi ke dalam dua kelas, kelas eksperimen dan kelas kontrol yang masing-masing terdiri dari 15 mahasiswa. Mereka diberi pengajaran selama tiga pertemuan untuk menerapkan teknik préciswriting dan pengajaran konvensional untuk penulisan recount mereka. Di kelas eksperimen, mahasiswa menerima pembelajaran menulis recount menggunakan précis-writing; sementara di kelas kontrol, mahasiswa menerima pembelajaran menulis recount menggunakan pengajaran konvensional. Data dikumpulkan melalui tes menulis recount sebelum dan sesudah pembelajaran. Untuk melihat apakah teknik précis-writing bisa meningkatkan kemampuan mahasiswa menulis recount, uji sampel Paired t-test dilakukan pada skor pre-test dan posttest mahasiswa di kelas eksperimen. Hasilnya menunjukkan bahwa teknik précis-writing secara signifikan mampu meningkatkan tulisan recount mahasiswa. Selain itu, uji sampel independent $t$-test juga dilakukan untuk melihat apakah précis-writing yang diterapkan di kelas eksperimen lebih efektif dibandingkan dengan pengajaran konvensional yang diterapkan 
di kelas control. Hasilnya menunjukkan bahwa nilai signifikansi $<0,05$ yang berarti bahwa précis -writing lebih efektif dalam meningkatkan tulisan recount mahasiswa dibandingkan dengan pengajaran konvensional. Oleh karena itu dapat disimpulkan bahwa teknik préciswriting mampu meningkatkan tulisan recount mahasiswa dan lebih baik daripada pengajaran konvensional.

Kata Kunci: Précis-writing, Teks recount, Mahasiswa laboratorium Bahasa Inggris.

\section{INTRODUCTION}

English, as one of the global languages in the world, has become a language of international communication in education, science, politics, business, and media (Crystal, 2006). In Indonesian education system, English is taught as a compulsory subject from secondary school level to university level. At the same time, English is an extra-curricular subject at elementary level curriculum (Prastyo, 2018). According to Cho \& Shin (2008) Indonesia has provided young children with the opportunity to learn English proficiently at an early age and to experience various cultures. By learning English, in addition to learning different cultures, students also learn the four English skills including listening, reading, speaking, and writing. They also learn other elements such as grammar, pronunciation, vocabulary, and spelling in oral and written communication.

One of the English skills that students have to learn is writing. Learning to write is primary and important to become skilled in the language and is crucial to academic achievement, employment, and promotion in the workplace (Graham \& Perin, 2007). Writing is one of the important language skills to make the language readable. Through writing, students learn how to express their ideas into written form. Also, students may use their writing skill as a communication tool for them to convey messages through written words. Writing is also one of the skills which influence the students' academic achievement.

One of the common types in writing is recount writing which is about writing a situation and experience occurring in the past and it has been recognized in the field of education (Miller \& McCardle, 2011). Recount writing may become a serious difficulty for students who do not have background knowledge of grammar especially in past tense. It is important for students to understand that producing good sentences or paragraphs is necessary to have knowledge of grammatical tense in recount writing. The idea of grammar is strongly intertwined with writing process which becomes an important consideration.

Students need to learn how to read written words for them to understand what they read. Numbers of skills are required to read a sentence that starts from recognizing each individual letter, letter group, and whole-word recognition to understand the planned meaning of the text (Nation, Clark, Wright \& Williams, 2006). Identifying the letter in the text is important for students because it can facilitate them to understand the meaning of the text. It does not only help them to understand the meaning of the 
text, but also helps them to learn grammar. By reading the text students can learn acceptable sentences and accurate grammar. It is shown that reading is very much related to the writing process.

It is important to consider the students' knowledge since it affects their writing (Puranik \& Lonigan, 2014). Writing does not only use words or symbols to write the text, but it also requires knowledge to convey ideas into writing. There are important components of writing that need to be learned by any language learners who want to have a good writing skill. They are content, organization, grammar, vocabulary, and mechanics. The five components emphasize that writing skill is not a simple thing for the students to learn (Glass, 2005). One of the functions the students need to understand the components is that they are an important tool for them to use to convey the message through written language. The need of understanding the components is that students can gain some knowledge and requirement of how to write grammatically.

Writing is the most complex skill, so it is very important for the students to learn it (National Center for Educational Statistics, 2012). Learning writing invites the students to pay attention to the five components of writing. Glass (2005) mentioned the five components to be considered in writing are content, organization, grammar, vocabulary, and mechanics. All the components are important to be assessed in writing.

The content is about the ideas to be considered in a written text. The organization is about the sequence of ideas showing the logical order of the writing. It is seen from the sequence of the first sentence to the next sentences or the first paragraph to the next paragraphs. Grammar accuracy is about how to produce meaningful and grammatically correct sentences. One important thing of the grammar accuracy is the subject, predicate, and the object are included in a sentence. It also guides how the subject and the verb agree depending on the tense of the sentence. The vocabulary is about the word usage and choice in writing while mechanics is about spellings of the words, punctuations, and writing tidiness. Weigle (2002) mentioned the same importance of those five components. Each of these components is given a maximum score in the evaluation. The maximum specified scores distributions are: content (30 points), organization (20 points), grammar accuracy (25 points), vocabulary (20 points), and mechanics (5 points).

\section{Recount text}

Recount text is a kind of text to tell the experiences that happened in the past, and to tell the sequence of past events. Knapp (2005) said that recount text is basically written out to make a report of an experience. The purpose is to retell the information to the reader (Shiahaan \& Shinoda, 2008). One of the most common characteristics in recount text is time where the information of time in recount text is in the past. It illustrates that the language in recount text is different from other texts because the language feature of recount text is the language in the past. 
There are generic structures that must exist in a recount text such as orientation, event, and reorientation. Orientation in recount text is about the opening paragraph which presents the participant, place, and time. Everything in the orientation must be clear, so it will help the reader to understand the text more easily. The event tells a series of events that occurred in the past while the reorientation is about the closing paragraph. It is not obligatory to tell the personal comment of the writer about the story. Therefore, it can be understood that recount text uses the past tense.

\section{Précis- Writing}

Précis-writing is defined as the technique which engages the process of a précis which is a summary of a written composition (Bromly \& Karen, 1983). It is believed that the technique of précis-writing is able to help students produce good quality recount writing. Précis-writing technique facilitates the students to summarize reading texts by noting important points from the text and then use them in their writing. This technique uses a reading text as a medium for writing.

According to Shanahan \& Lomaz (1986) in their research on an analysis and comparison of theoretical models of the reading-writing relationship, identified that reading has an effect on writing, and writing has an effect on reading for both $2^{\text {nd }}$ and $5^{\text {th }}$ graders. When students read a text, in addition to knowing the structure of the text, they will also learn and have a lot of knowledge about the text. From reading a text, students can use their knowledge to be written into their own writing. Therefore, it is explainable that reading can help students to have good quality in writing.

Précis-writing technique facilitates the students to summarize a reading text by noting important points from the text. It can be the vocabulary, content, or other elements depending on the readers' need which is believed to be able to help students in their recount writing. It is hoped, at the end of using this technique, the students will have a good feeling and confidence in writing. It will be easier for them to understand on how to put the words into their own writing, so it might facilitate their writing process.

Bromly \& Karen (1983) said that précis-writing engages the progress of a précis which is a summary of a written composition. One of the things to be done is that the technique is applied by giving reading text to the students. The students are required to make a summary of information obtained from the reading text. They are also suggested to avoid the difficult words in the text by using their own words. This will make writing easier. Taylor \& Berkowitz (1980) investigated that sixth graders who wrote the sentences by making summary after reading a social study passage felt easier to understand and remember what was read than the students who only answered questions after reading the text or the students who only read the certain parts of the text. This technique illustrates that by summarizing the text that has been read makes the students easier to convey the text understanding into their own writing. The other 
advantage of using this technique after reading a text is that the students will directly pay attention to the structure of each sentence in a text. At that time, they can apply it into their own writing. As a result, they will understand how to produce sentences with good grammar.

Hidi \& Aderson (1986) identified that there are some processes of using préciswriting technique. The first is the comprehension of the original text where it involves the students to understand the reading text. The second is the ability to choose and distinguish the main ideas from the original text. This process is used to get accurate information from the original text. The third is the transformation of the main ideas into the students' written text. This process is carried out to convey the main ideas that have been obtained into students' writing. The last process is the adoption of the appropriate writing. This process involves how the students write accurately. Based on the process, it is known that reading text is an important part of using the préciswriting technique.

There are some studies have been conducted with similar type of writing technique. First, it is the role of formal schemata in the development of précis-writing. Leila, Biook \& Mahnaz (2014) conclude that précis-writing could help students to perform better in writing than the control group. It is used to learn how to write well by means of précis-writing. It involved thirty students who received treatment of précis-writing in the study. They believe that précis-writing could contribute better writing skill to learners compared to those who only write with their own background knowledge. Both, their study and this study have similarities in terms of the application of précis writing technique. The difference of both studies is on the expected goal to achieve. The previous study aims to explore the role of formal schemata while this study aims to see if there is any improvement of students' recount writing.

Second, the study conducted by Bromly \& Karen (1983) is entitled "The use of précis-writing and outlining to aid learning social studies content". This study claimed that the reading text is important to influence learning and attitudes toward learning. Two groups of fifth grader are trained to apply the techniques of précis-writing and outlining to their reading in social studies. The student's achievements are measured in writing by giving a multiple choice and an essay test. This study and the present study have similarities in using the technique of précis-writing but they also have difference because in the previous study, they use two techniques to influence learning and attitude toward learning while in the present study only uses one technique of précis writing to improve students' recount writing. The present study aims to find out whether précis-writing is effective in improving students' recount writing or not and whether or not précis-writing improved students' recount writing better compared to conventional teaching. Thirty of third level English laboratory students participated in this study.

Third, the research is about the effect of précis-writing instruction on the creation 
of cohesive text by Iranian high school EFL learners written by Karimi \& Regheb (2017). They explore the effect of précis-writing on the creation of a compact text, and 40 female students were selected as the participant. The students in the control class were taught by some grammatical structures while the students in the experimental class received the lesson of précis-writing. The result of the research indicates that the participant in the experimental class performed better in producing cohesive text. The research concluded that teaching précis can improve the students' writing ability. The researches above show that this research is same with the previous research in using the technique of précis-writing to improve the student's writing. Following this section, theoretical review is discussed.

\section{METHOD}

\section{Participant}

The population of this study was third level English laboratory students at Universitas Bandar Lampung consisting of 318 students. There were thirty of third level English laboratory students participated in this study selected through cluster random sampling. They were divided into two intact classes, the experimental class and the control class of 15 students respectively. This study focused on students of level 3 because they had already experienced learning past tense in their previous level.

\section{Instrument}

In order to collect the data for this study, recount writing tests were used as a pretest and posttest in both the experimental class and the control class. In the pretest, participants were asked to write their bad experience. The students were asked to write their bad experience by using their own words. It was aimed to see the students' recount writing before having the treatment. In the experimental class, participants received treatment using précis-writing. While the treatment in control class was a regular conventional teaching of past tense. The teacher just explained the sentence of past tense and asked them to write sentences of past tense. The students in both classes received the treatment in 3 meetings. After having the treatment, the students were asked to write their good experience in the posttest. They were asked to write their good experience by using their own words. It was aimed to see the improvement of students' recount writing after the treatment. In this procedure, the students wrote a paragraph of recount text by using their own words and knowledge after the treatment both in the experimental class and the control class.

\section{Data Analysis}

Data gathered was analyzed using independent samples t-tests and pairedsamples $t$-tests. In order to answer the main research question, the data were analyzed 
using descriptive and inferential analyses. The statistical software package for social science (SPSS) version 23 is used for analysis of quantitative data. Because the researcher was not necessarily concerned about Type I of error, an alpha error $\alpha=$ .05 was chosen by convention with $95 \%$ confidence level $(p<.05)$. For the nature of the classroom research, group means rather than individual scores are used as the units of analysis (Prastyo, 2018). Every statistical test has assumptions which explain when it is and is not reasonable to perform a statistical test (Prastyo, 2018). Therefore, assumption tests were performed in this study

The following are the main assumptions underlying t-test which include normality assumption and homogeneity of variances. Care was taken in the present study to ensure all the assumptions were satisfied. The results of normality tests showed that the significance value of the pretest score in the control class is .200 while in the experimental class is .098. Therefore, it illustrates that the data are normally distributed since the significant value of both classes is higher than .05. Another result shows that the significance value of the posttest score in the control class is .181 while in the experimental class is .200 . Therefore, it showed that the data of posttest scores are normally distributed since the significance value of both classes is higher than .05 .

The results of the homogeneity test showed that the significance value of pretest scores in both classes is .670. It illustrates that the significance value of both classes is higher than .05. Therefore, the data are homogeneous. Another result of the homogeneity test showed that the significance value of posttest scores in both classes is .141. It illustrates that the significance value of both classes is higher than .05 . Therefore, the data are homogeneous.

\section{RESULT AND DISCUSSION}

From the data collected through pretest and posttest, it can be seen that students' recount writing scores are different in the four sets of data. In the pretest, the experimental class and the control class indicated different recount writing scores with average scores of 52.2 in the control class and 60.8 in the experimental class. This indicated that at the beginning of the study, participants in both classes have different recount writing scores. In the posttest data, it can also be seen that participants have different recount writing scores of 67.8 in the control class and 85.46 in the experimental class which indicated that participants have different recount writing scores at the end of the study (see table 1 below). 
Table 1: Participants' Recount Writing Scores

\begin{tabular}{|l|c|r|r|r|r|}
\hline \multirow{2}{*}{ Group } & \multirow{2}{*}{ N } & \multicolumn{2}{c|}{ Mean } & \multicolumn{2}{c|}{ SD } \\
\cline { 3 - 6 } & & \multicolumn{1}{c|}{ Pre-test } & \multicolumn{1}{c|}{ Post-test } & \multicolumn{1}{c|}{ Pre-test } & \multicolumn{1}{c|}{ Post-test } \\
\hline Control & 15 & 52.2000 & 67.8000 & 7.9570 & 7.2918 \\
\hline Experiment & 15 & 60.8000 & 85.4667 & 10.4690 & 4.7187 \\
\hline Total Sample & 30 & 56.5000 & 76.6333 & 9.2130 & 6.0053 \\
\hline
\end{tabular}

In order to answer the research question whether or not précis-writing is effective in improving students recount writing and whether or not précis-writing is more effective compared to the conventional teaching, statistical analyses were conducted to the data. Independent samples $t$-tests were performed three times to see if the participants have a significant different recount writing scores at the beginning of the study, at the end of the study, and whether their improvement scores during the study are significantly different from each other. In addition to those independent samples $t$-tests, two paired-samples $t$-tests were also performed to see if précis-writing implemented in the experimental class and the conventional teaching implemented in the control class are effective in improving students recount writing.

Independent samples t-test of the pretest scores results indicated that both classes have a significantly different recount writing scores at the beginning of the study with significant value .05 . This result indicated that even though participants are from the same level of level 3 in English Laboratory, they possess different competence in their recount writing (see table 2).

Table 2: Independent Sample T-Test of Pretest Scores

\begin{tabular}{|l|c|c|c|}
\hline \multirow{2}{*}{ Group } & \multirow{2}{*}{ N } & Mean & \multicolumn{1}{c|}{ SD } \\
\cline { 3 - 4 } & & Pre-test & Pre-test \\
\hline Control & 15 & 52.2000 & 7.9570 \\
\hline Experimental & 15 & 60.8000 & 10.4690 \\
\hline
\end{tabular}

Independent Samples T-test

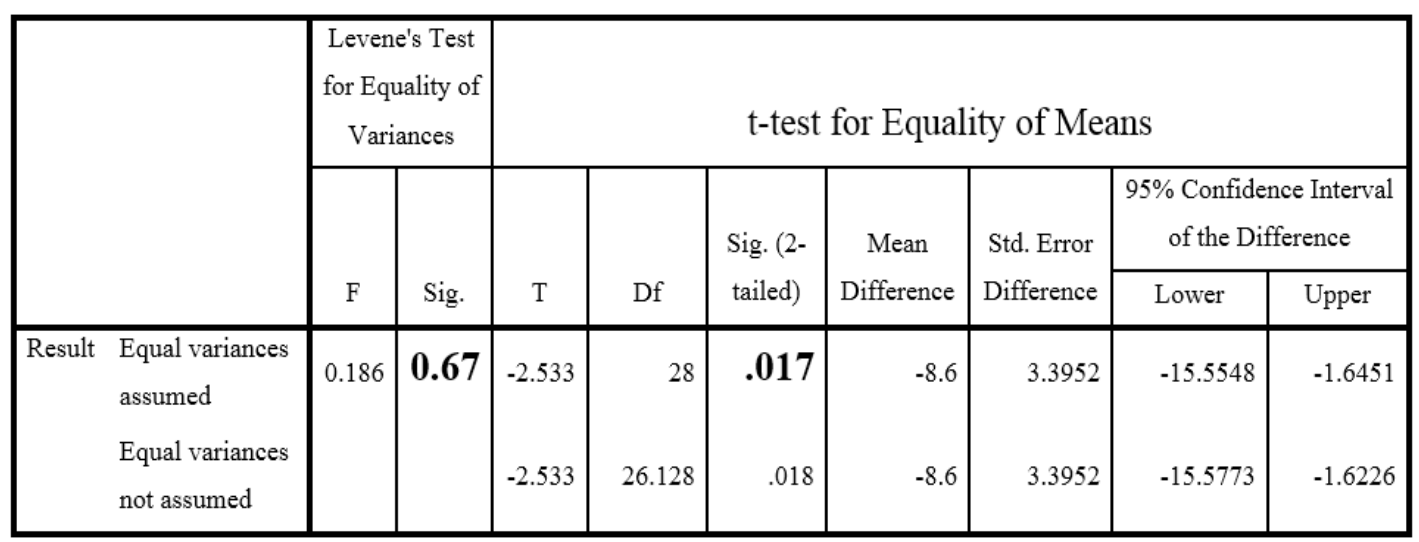

Another independent samples $t$-test was performed to see if the participants have different recount writing ability at the end of the study. The results of independent samples $t$-test on the posttest scores showed the significance value (2-tailed) is .017 
which is lower than the signifcant level of .05 . It means that the two classes have significantly different recount writing ability at the end of the study (see table 3).

Table 3: Independent Samples T-Test of Posttest Scores

\begin{tabular}{|l|c|r|r|}
\hline \multirow{2}{*}{ Group } & \multirow{2}{*}{ N } & \multicolumn{1}{c|}{ Mean } & \multicolumn{1}{c|}{ SD } \\
\cline { 3 - 4 } & & Post-test & \multicolumn{1}{c|}{ Post-test } \\
\hline Control & 15 & 67.8000 & 7.2918 \\
\hline Experimental & 15 & 85.4667 & 4.7187 \\
\hline
\end{tabular}

Independent Samples Test

\begin{tabular}{|c|c|c|c|c|c|c|c|c|c|c|}
\hline & \multicolumn{2}{|c|}{$\begin{array}{l}\text { Levene's Test for } \\
\text { Equality of } \\
\text { Variances }\end{array}$} & \multicolumn{7}{|c|}{ t-test for Equality of Means } \\
\hline & & \multirow[b]{2}{*}{ F } & \multirow[b]{2}{*}{ Sig. } & \multirow[b]{2}{*}{$\mathrm{T}$} & \multirow[b]{2}{*}{$\mathrm{Df}$} & \multirow{2}{*}{$\begin{array}{l}\text { Sig. (2- } \\
\text { tailed) }\end{array}$} & \multirow{2}{*}{$\begin{array}{l}\text { Mean } \\
\text { Difference }\end{array}$} & \multirow{2}{*}{$\begin{array}{l}\text { Std. Error } \\
\text { Difference }\end{array}$} & \multicolumn{2}{|c|}{$\begin{array}{l}95 \% \text { Confidence } \\
\text { Interval of the } \\
\text { Difference }\end{array}$} \\
\hline & & & & & & & & & Lower & Upper \\
\hline Result & $\begin{array}{l}\text { Equal variances } \\
\text { assumed } \\
\text { Equal variances } \\
\text { not assumed }\end{array}$ & 2.290 & .141 & $\begin{array}{l}-7.878 \\
-7.878\end{array}$ & $\begin{array}{l}28 \\
23.976\end{array}$ & $\begin{array}{l}.000 \\
.000\end{array}$ & $\begin{array}{l}-17.666 \\
-17.666\end{array}$ & $\begin{array}{l}2.242 \\
2.242\end{array}$ & $\begin{array}{l}-22.2 \\
-22.2\end{array}$ & -13.072 \\
\hline
\end{tabular}

Based on the two independent samples $t$-tests statistical analysis on the pretest scores and the posttest scores of the experimental and the control class, the results showed that both classes have a significantly different recount writing scores at the beginning and the end of the study. Now, the question is whether or not précis-writing is effective in improving students recount writing and whether or not précis-writing is more effective compared to the conventional teaching.

In order to answer the question whether or not précis-writing is effective in improving students recount writing, paired samples t-test was performed on students' pretest and posttest scores in the experimental class. The results (see table 4) indicated that students in the experimental class significantly improved their recount writing score with significant level of $<.05$. This indicated that précis-writing implemented in the experimental class in this study is effective in improving students recount writing. Another paired-samples t-test was also performed on participants' pretest and posttest scores in the control class. This is to find out if the conventional teaching implemented in this study is effective in improving students' recount writing score. The results showed a significant level of .05 which indicated that the conventional teaching implemented in the control class of this study is also effective in improving students' recount writing scores. 
Table 4: Paired-Samples T-Ttest of the Experimental Class Paired Samples Statistics

\begin{tabular}{|ll|l|l|r|r|}
\hline & & Mean & N & Std. Deviation & Std. Error Mean \\
\hline Pair 1 & Pretest & 60.8000 & 15 & 10.4690 & 2.7030 \\
& Posttest & 85.4667 & 15 & 4.7187 & 1.2183 \\
\hline
\end{tabular}

Paired Samples Test

\begin{tabular}{|c|c|c|c|c|c|c|c|c|c|}
\hline & & \multicolumn{5}{|c|}{ Paired Differences } & \multirow[b]{3}{*}{$\mathrm{T}$} & \multirow[b]{3}{*}{$\mathrm{df}$} & \multirow{3}{*}{$\begin{array}{l}\text { Sig. (2- } \\
\text { tailed) }\end{array}$} \\
\hline & & \multirow[b]{2}{*}{ Mean } & \multirow{2}{*}{$\begin{array}{c}\text { Std. } \\
\text { Deviation }\end{array}$} & \multirow{2}{*}{$\begin{array}{c}\text { Std. Error } \\
\text { Mean }\end{array}$} & \multicolumn{2}{|c|}{$\begin{array}{c}95 \% \text { Confidence } \\
\text { Interval of the } \\
\text { Difference }\end{array}$} & & & \\
\hline & & & & & Lower & Upper & & & \\
\hline Pair 1 & $\begin{array}{l}\text { Posttest - } \\
\text { pretest }\end{array}$ & 24.666 & 9.751 & 2.5178 & 30.0669 & 19.2663 & 9.79 & 14 & .000 \\
\hline
\end{tabular}

However, the results of previous statistical analyses do not yet answer the research question in this study whether or not précis-writing is more effective compared to the conventional teaching. Therefore, an independent samples $t$-test on the difference posttest-pretest scores of both classes was also performed.

Table 5: Independent Sample T-Test of Improvement Scores

Group Statistics

\begin{tabular}{|ll|c|c|c|}
\hline & & & & \\
Class & & $\mathrm{N}$ & Mean & Std. Deviation \\
\hline differences & Control & 15 & 15.6000 & 8.72435 \\
& Experimental & 15 & 24.6667 & 9.75168 \\
\hline
\end{tabular}

Independent Samples Test

\begin{tabular}{|c|c|c|c|c|c|c|c|c|c|c|}
\hline & \multicolumn{2}{|c|}{$\begin{array}{c}\text { Levene's Test for } \\
\text { Equality of Variances }\end{array}$} & \multicolumn{7}{|c|}{ t-test for Equality of Means } \\
\hline & & \multirow[b]{2}{*}{$\mathrm{F}$} & \multirow[b]{2}{*}{ Sig. } & \multirow[b]{2}{*}{$\mathrm{T}$} & \multirow[b]{2}{*}{ Df } & \multirow{2}{*}{$\begin{array}{l}\text { Sig. (2- } \\
\text { tailed) }\end{array}$} & \multirow{2}{*}{$\begin{array}{c}\text { Mean } \\
\text { Difference }\end{array}$} & \multirow{2}{*}{$\begin{array}{l}\text { Std. Error } \\
\text { Difference }\end{array}$} & \multicolumn{2}{|c|}{$\begin{array}{c}95 \% \text { Confidence } \\
\text { Interval of the } \\
\text { Difference }\end{array}$} \\
\hline & & & & & & & & & Lower & Upper \\
\hline Result & $\begin{array}{l}\text { Equal variances } \\
\text { assumes } \\
\text { Equal variances not } \\
\text { assumes }\end{array}$ & .255 & .618 & $\begin{array}{l}-2.684 \\
-2.684\end{array}$ & 28 & $\begin{array}{l}.012 \\
.012\end{array}$ & $\begin{array}{l}-9.0666 \\
-9.0666\end{array}$ & $\begin{array}{l}3.3784 \\
3.3784\end{array}$ & $\begin{array}{l}-15.9 \\
-15.9\end{array}$ & $\begin{array}{l}-2.1462 \\
-2.1423\end{array}$ \\
\hline
\end{tabular}

As can be seen in the table 5 above, the significant level of Lavene's test .618 which is $>.05$ and therefore the results of Sig. ( 2 taided) used is in the second 
line (.012). The result illustrated that the significant value (2-tailed) is lower than .05 which means that the data is not equal. It means that précis-writing improve students' recount writing in the experimental class better than the improvement gained by the participants in the control class which received treatment using conventional teaching. This result indicated that even though the students did not have equal recount-writing ability at the beginning of the study, however the result of independent sample $t$-test of the improvement score between two classes indicates that précis-writing improved students' recount writing significantly better than the conventional teaching.

\section{DISCUSSION}

The result of this study illustrated that the students' scores of both the control and experimental classes are quite low in the pretest. The mean score of the control class is 52.2 while in experimental class is 60.8 . In the pretest, the students were asked to write a recount writing with the topic "My Bad Experience". In general, the result was that the recount writing in the pretest was unorganized. Even though the recount writing was good enough and it contained many paragraphs, their recount writing was still rather rambling.

During the treatment, it was found that the students in both the experimental and the control classes were confused with what they should write. They had the ideas, but they were confused about how to elaborate them. However, in the experimental class, it was found that the technique of précis-writing could help them elaborate their ideas into their recount writing. It happened because after the treatment by using précis-writing, the result of recount writing in the posttest was related to the topic and more specific than the result of recount writing in the pretest. For that reason, the result of their recount writing after the treatment of précis-writing was better than before because they experienced to write the summary of the recount text in the treatment of using précis-writing technique. Meanwhile, in control class, they received a conventional teaching of past tense, but some of the students were still confused of what they should write. The students improved their recount writing by elaborating their ideas after the conventional teaching of past tense. However, the improvement was not as good as those who received précis-writing.

As the result, the scores of both the control and the experimental classes in the posttest improved. The result shows that the mean score of the control class in the posttest is 67.8 . the mean score increased 15.6 points from the pretest score. It means that they have improved their recount writing ability compared to the pretest result. Meanwhile, the mean score of the experimental class in post-test is 85.5 which increased 24.7 points from the pretest mean score. It means that participants in the experimental class improved their recount writing ability compared to the pretest result.

The result showed that the scores of the experimental class increased significantly 
and was higher than those of the control class. It is 9.1 points higher than the control class scores. So, it can be concluded that students who received treatment by using précis-writing had higher scores than those who received treatment by conventional teaching.

After learning writing using précis-writing in three meetings, students achieved better writing. They could minimize or even avoided the errors in their writing. Based on the result of the post-test in experimental class, the students improved their writing, especially in grammar, vocabulary, content, organization and mechanics. In the experimental class, students achieved significant improvement in their writing. The result is not different with the previous researches which use the same technique of précis-writing. The result of the research indicated that précis-writing is a good technique to improve students' recount writing.

\section{CONCLUSION}

After analyzing the result of the study, there were some indications to be summarized. First, the students' scores of both the control and the experimental classes were quite low in the pretest. The mean scores of the control class is 52.2 while in experimental class is 60.8. In the pretest, most students made many errors in writing especially in vocabulary, grammar, and spelling. Second, the treatments provided during the study (précis-writing and conventional teaching) improved students' recount writing ability. It was also found that the students' scores of the experimental class improved significantly and was higher than that of the control class. The students in the experimental class improved their recount writing mean score by 24.7 points, while the students in the control class improved their recount writing mean score by 15.6 points. The statistical analysis suggested that the null-hypothsis $\left(\mathrm{H}_{\mathrm{o}}\right)$ is rejected and the alternative hypothesis $\left(\mathrm{H}_{\mathrm{a}}\right)$ is accepted which means that Précis-writing is found to be more effective in improving students' recount writing of the third level English Laboratory students of Universitas Bandar Lampung. These results implicate that précis-writing implemented in the experimental class is more effective compared to the conventional technique implemented in the control class in assisting students' recount writing. Therefore, it is suggested that précis-writing should be used by teachers and lectures in teaching and improving students' recount writing.

Based on the results, some suggestions can be provided for students, teachers and lecturers as well as future researchers. First, for students, as précis-writing is found to be effective to facilitate students' writing recount text. Therefore, students are suggested to read a lot of recount texts in order to be able to improve their skill in writing recount text and their writing skill in general. By reading a lot of recount texts, it will not only improve their quality in writing, but it also helps them to improve their reading skill as well. Second, for the teachers and lecturers, the technique of

précis-writing can be used as an alternative technique in teaching recount text as it was 
found, in this research, to be an effective way to improve students' recount text writing. Third, for future researchers, some suggestions can be outlined as follows: first, as the participants in this research are only 30 students, future researchers can involve more number of participants to provide more reliable results. Second, as the participant of this research studied in laboratory program, which is not regular class, future researchers can invite regular students studying in regular classes and implement précis-writing technique. Third, as this research focused only on the quantitative side of the research design which missing the qualitative side, the students and teachers' perceptions in using précis-writing technique was neglected therefore future researcher is suggested to cover both sides of quantitative and qualitative to explore more comprehensive results.

\section{REFERENCES}

Bromley, Karen, D, A. (1983). Précis-writing and Outlining: Aids to Learning Social Studies.

Cho, E. \& Shin, S. (2008). Survival, Adjustment, and Acculturation of Newly Immigrated Families with School-age Children: Cases of Four Korean Families. Diaspora, Indigenous, and Minority Education,

Glass, K. T. (2005). Curriculum Design for Writing Instruction. California: Corwin Press.

Graham, S. \& Perin, D. (2007). A Meta-Analysis of Writing Instruction for Adolescent Students. Journal of Educational Psychology. 99, 445-476.

Crystal, David. (2006) English as a Global Language. Cambridge University Press, Cambridge.

Hidi, S. \& Anderson, V. (1986). Producing Written Summaries: Task Demands, Cognitive Operations, and Implications for Instruction. Review of Educational Study, 56 (4),473-493.

Karimi, L. \& Regheb, M.T. (2017). Effect of Precis-Writing on the Creation of Cohesive Text by Iranian High School EFL Learners. Journal of English Language Pedagogy and Practice, pp.97-114.

Leila, A.A.H, Biook, B., \& Mahnaz, S. (2014). The Role of Formal Schemata in The Development of Précis-Writing in An Iranian EFL Context. Social and Behaviors Science, 98,207-211

Miller, B., \& McCardle, P. (2011). Reflections on The Need for Continued Study on Writing. Reading and Writing, 24(2), 121-132.

Nation,K., Clarke, P., Wright, B., \& Williams, C. (2006). Patterns of Reading Ability in Children with Autism Spectrum Disorder. Journal of Autism and Developmental Disorders, 36, 911-919.

National Center for Education Statistics. (2012). The Nation's Report Card: Writing 2011 (No. NCES 2012- 470). Washington, DC: Institute of Education 
Sciences, U.S. Department of Education.

Peter Knapp. (2005) Genre, Text, and Grammar: Sydney University of New South Wales.

Prastyo, Y.D., (2018). Effect of Cooperative Learning on Student Teachers' Communicative Competence in Indonesia. PhD Dissertation, University of Limerick, Ireland.

Puranik, C. S.,\& Lonigan, C. J. (2014). Emergent Writing in Preschoolers: Preliminary Evidence for A Theoretical Framework. Reading Study Quarterly, 49(4), 453-467.

Shanahan, T., \& Lomax, R. G. (1986). An Analysis and Comparison of Theoretical Models of The Reading-Writing Relationship. Journal of Educational Psychology, 78(2), 116-123.

Siahaan, S., \& Shinoda, K. (2008). Generic Text Structure. Yogyakarta: Graha Ilmu.

Taylor, B., \& Berkowitz, S. (1980). Facilitating Children's Comprehension Material. In 29th Yearbook of the National Reading Washington, D. C.: National Raying Conference.

Weigle, S. (2002). Assessing Writing. Cambridge University Press: United Kingdom. London. 